\title{
Original paper \\ Primary and secondary textures of dolomite in Eppawala carbonatites, Sri Lanka: implications for their petrogenetic history
}

\author{
Nadeesha S. MADUGALLA ${ }^{1}$, Amarasooriya PITAWALA ${ }^{2 *}$, Geeth MANTHILAKE ${ }^{3}$ \\ ${ }^{1}$ Department of Physical Sciences, Faculty of Applied Sciences, South Eastern University, University Park, 32360 Oluvil, Sri Lanka \\ ${ }^{2}$ Department of Geology, University of Peradeniya, 20400 Peradeniya, Sri Lanka; apitawala@pdn.ac.lk \\ ${ }^{3}$ Université Blaise Pascal, 5 rue Kessler, 63038 Clermont-Ferrand, France \\ ${ }^{*}$ Corresponding author
}

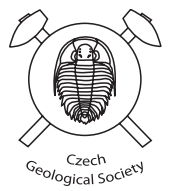

Textural studies of carbonate minerals over the past three decades revealed that their textures are useful tool for understanding of petrogenesis of carbonatites. Petrographic, cathodoluminescence (CL) and electron-microprobe studies on textures of calcite and dolomite were performed for interpretation of evolution of Eppawala carbonatites in Sri Lanka. The studied carbonatites are dominated by calcite with subordinate dolomite. Calcites occur in two different morphological forms, reflecting two generations: as grains with dolomite inclusions (type-1) and dolomite-free (type-2) ones. Dolomites were subdivided into five distinct morphological types: randomly distributed, coarse-grained dolomite (type-1), rod-shaped or vermicular dolomite microcrysts within the type-1 calcite (type-2), inclusions of dolomite within the type 1 calcite forming plug- or wedge-shaped arrangements (type-3), dolomite microcrysts along the grain boundaries of the type 1 calcite (type-4) and clusters of dolomite crosscutting the type 1 calcite (type-5).

The geochemical results indicate that these five morphological types accounts for three different generations of dolomites. Type- 1 dolomite and type- 1 calcite are interpreted as primary magmatic. Type- 2 and type- 3 represent exsolved dolomite formed by exsolution from type- 1 calcite. Type- 4 and type- 5 dolomites are recrystallized and reorganized dolomites of exsolved type- 2 and type- 3 dolomites. Type- 2 calcite reflects later recrystallization event. The composition of type- 1 calcite indicates minimum temperatures of exsolution of c. $650{ }^{\circ} \mathrm{C}$. The exsolution and recrystallization kinetics reflected the equilibration of carbonatite magma at two crustal depths during the petrogenesis of Eppawala carbonatite. The re-localization may have been related to the deformations experienced by the country rocks.

Keywords: carbonatites, calcite, dolomite, exsolution, recrystallization

Received: 15 March 2016; accepted: 24 August 2017; handling editor: V. Rapprich

\section{Introduction}

Despite being rare mantle-derived rocks, carbonatites have been extensively studied during last few decades as they provide striking evidence on the nature and evolution of the Earth's mantle (Bell and Blenkinsop 1987; Wyllie et al. 1990; Lentz 1999; Bell and Tilton 2001; Halama et al. 2008; Bell and Simonetti 2010; Johnson et al. 2010). Geochemical characteristics such as traceelement chemistry, composition of stable and radiogenic isotopes and chemistry of fluid inclusions are the widely used aspects in such studies (Wyllie et al. 1990; Tilton and Bell 1994; Bell 1998; Le Roex and Lanyon 1998; Bell and Tilton 2001; Ray and Ramesh 2006; Bell and Simonetti 2010; Johnson et al. 2010). However, there have been only few investigations on carbonatite generation and evolution based on the textures of carbonate minerals (Katz and Keller 1981; Cooper and Reid 1991; Zaitsev and Polezhaeva 1994).

Among the reported textures associated with carbonate minerals in carbonatites, comb-layering (Katz and Keller 1981), with pilotaxitic and spinifex textures
(Cooper and Reid 1991) have been well studied. Such studies revealed that textures of carbonate minerals are important tools to interpret the specific conditions of super cooling, cooling rates and super-saturation prevailing in the corresponding magmatic body. Additionally, the intergrowth textures of calcite and dolomite, where dolomite forms vermicules, plates, rods, segmented rods, blebs and xenomorphic grains have been reported from certain carbonatites (Van der Veen 1965; Zaitsev and Polezhaeva 1994). These textures yielded the composition of the primary carbonate phases, information on crystal-melt segregation and crystallization temperature as well as depth and timing of sub-solidus processes that have modified them (Van der Veen 1965; Cooper and Reid 1991; Wall et al. 1993; Zaitsev and Polezhaeva 1994). In the past several decades, intergrowth formation mechanisms have been subject to discussion. Exsolution (Goldsmith 1983; Puhan 1984) or metasomatism with recrystallization (Zaitsev and Polezhaeva 1994) could lead to the formation of such textures. However, numerous questions still remain open regarding the actual origin of such textures. 
Dolomite exsolution from magnesian calcite produces a variety of textures (Harker and Tuttle 1955; Goldsmith 1960; Goldsmith and Newton 1969; Puhan 1984) that can form in carbonatites during the cooling of the melt. Subsequently, carbonatites can commonly undergo deuteric alteration (Morogan and Martin 1985; Morogan 1994), which can modify particularly the primary composition and the textures of carbonate minerals (Zaitsev and Polezhaeva 1994; Keller and Zaitsev 2006; Skelton et al. 2007). Furthermore, unlike silicates, carbonate minerals are highly sensitive to physico-chemical changes and can easily be deformed due to high crystal-plasticity even at very low P-T conditions (Burkhard 1990). Therefore, textures of carbonate minerals can be used to interpret the crystallization and emplacement, as well as the postemplacement history (Cooper and Reid 1991; Zaitsev and Polezhaeva 1994; Mposkos et al. 2006).

The carbonatite intrusions exposed at Eppawala in north-central Sri Lanka have intruded near to the axis of na 1976; Pitawala et al. 2003; Pitawala and Lottermoser 2012). According to the $\mathrm{Rb}-\mathrm{Sr}$ and $\mathrm{Sm}-\mathrm{Nd}$ isotopic $\mathrm{N}-\mathrm{S}$ trending synform as oval-shaped bodies (Jayawarde-

data, the Eppawala carbonatites are late Neoproterozoic (550 Ma: Weerakoon et al. 2001), post-dating the metamorphic peak of the country rocks ( 610 Ma: Kröner and Williams 1993). Previous studies on mineral textures revealed that the calcite and dolomite of Eppawala carbonatites occur as different morphological forms, including three distinct morphological types of dolomite and two generations of calcites (Pitawala and Lottermoser 2012) that may have formed during solidification of magma and later hydrothermal processes.

The purpose of this study is to use combined morphological features and geochemical characteristics of spectacular textures of carbonate minerals for further understanding of the genesis and evolution history of the Eppawala carbonatites.

\section{Geological setting}

The basement of Sri Lanka is built predominantly by high-grade metamorphic rocks (Fig. 1a), which can be subdivided in to four main units; the Highland Complex (HC), the Wanni Complex (WC), the Vijayan Complex (VC) and the Kadugannawa Complex (KC) based on their age, metamorphic grade and structural features (Kröner et al. 1991; Cooray 1994). The Eppawala carbonatite bodies are exposed in the $\mathrm{WC}$ close to their tectonic boundary with the HC.

The HC is composed of meta-sedimentary rocks such as pelitic to semi-pelitic gneiss, quartzite, marble and calc-silicate (Cooray 1984, 1994) as well as late- to post-tectonic granitoids and mafic magmatic rocks (Kröner et al. 2003) that yield Nd-model ages from 2.0 to $3.4 \mathrm{Ga}$ (Milisenda et al. 1988, 1994). Metamorphism of all the sedimentary and igneous

Carbonatite

Charnockitic gneiss

Granitic gneiss

Hornblende- biotite gneiss

Phosphate ore

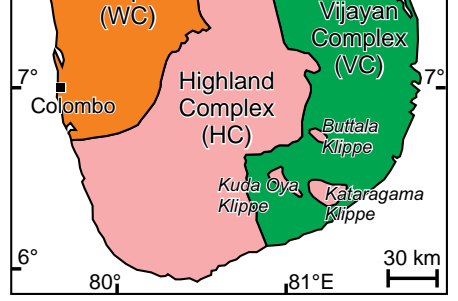

Hornblende-biotite

migmatitic gneiss

Marble

Strike and dip

of the foliation

Trace of antiform axial plane
Fig. 1a - Major geological units of the Precambrian basement of Sri Lanka (Kröner et al. 1991; Cooray 1994); b - Simplified geological map of the ter Pitawala and Lottermoser 2012), showing the investigated carbonatites within the rocks of the Wanni Complex. Eppawala with surrounding area (af- 
lithologies in the $\mathrm{HC}$ has occurred between 550 and 600 Ma (Milisenda et al. 1994).

Major rock types in the WC include granitic, monzonitic, charnockitic and enderbitic gneisses, migmatites, metasediments and late- to post-tectonic granites (Kröner et al. 2003). Most of the meta-sediments in the WC occur close to the boundary with the HC (Kehelpannala 1997). Previous geochronological studies of the Wanni Complex yielded $\mathrm{Nd}$ model ages in the range of 1.0-2.0 Ga (Milisenda et al. 1988, 1994). These rocks have been metamorphosed under upper amphibolite to granulite-facies conditions (Cooray 1994) at 550-600 Ma (Milisenda et al. 1994). Zircon ages and Nd model ages of the $\mathrm{HC}$ and WC show significant differences indicating separate origins for these two terrains (Kröner et al. 2003). However, the boundary between the $\mathrm{HC}$ and the $\mathrm{WC}$ is still poorly defined.

The Eppawala carbonatites form a N-S trending belt of oval-shaped bodies that intruded into the granitic gneiss of the WC associated with migmatitic hornblendebiotite and charnockitic gneisses (Fig. 1b; Pitawala et al. 2003; Manthilake et al. 2008).

\section{Methods}

A detailed petrographic study on both hand specimens and polished thin sections was performed using more than 40 samples from representative carbonatites. Alizarin Red-S stained (Friedman 1959) polished specimens and polished thin sections were used to distinguish matrix dolomite as well as dolomite microcrysts within the discrete calcite grains. The size, shape and optical orientations of dolomite microcrysts within calcite hosts were studied and their modal percentages were determined.

Intergrowths of carbonate minerals were examined in detail using back-scattered electron (BSE) images obtained using a JEOL JSM-5910 LV scanning electron microscope equipped with an OPEA cathodoluminescence (CL) detector at the Laboratoire Magmas et Volcans, Université Blaise Pascal, France. The OPEA detector enables CL imaging over a spectral window of 170 to $2000 \mathrm{~nm}$. Optional is the use of variable pressure (LV mode), which has a vacuum gradient from 1 to $130 \mathrm{~Pa}$. The LV mode permits the analysis without the necessity for carbon coating of the sample. The excitation for the BSE and CL measurements was provided by a $15 \mathrm{kV}$ electron beam at a working distance of $\sim 20 \mathrm{~mm}$.

An X-ray powder diffraction analysis was performed on Siemens 5000 diffractometer using $\mathrm{Cu} \mathrm{K}_{\alpha}$ radiation $(40 \mathrm{kV}$ and $30 \mathrm{~mA}$ ) and graphite monochromator in order to identify carbonate minerals. The scanning step size was $0.020^{\circ}$

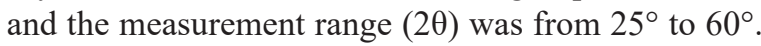

Chemical compositions of texturally different carbonates were analyzed using a CAMECA SX 100 electron microprobe equipped with four wavelength-dispersive spectrometers (WDS) at the Laboratoire Magmas et Volcans, Université Blaise Pascal, France. The measurements were performed at an accelerating voltage of $15 \mathrm{kV}$ and with $10 \mathrm{nA}$ beam current. The WDS method was used to measure the chemical compositions of mineral phases. Data correction was made using the conventional ZAF method. The standards used for these analyses were calcite (Ca), periclase (Mg), rhodochrosite (Mn), siderite $(\mathrm{Fe})$, celestite $(\mathrm{Sr})$, albite $(\mathrm{Na}, \mathrm{Si}), \mathrm{Al}_{2} \mathrm{O}_{3}(\mathrm{Al})$ and orthoclase (K).

\section{Results}

\subsection{Carbonate mineralogy}

Calcite is the most abundant mineral found in the studied carbonatites, accounting for c. 65 to 70 vol. \%. It commonly occurs as coarse anhedral grains; the sizes of grains vary from c. $0.5 \mathrm{~mm}$ to $2 \mathrm{~cm}$ (Fig. 2). Calcite grains commonly have sutured and interpenetrating boundaries with neighbouring dolomite grains. Furthermore, most of them show cloudy appearance under plane polarized light (PPL) and are rich in small dolomite inclusions (Figs 2 and 3a). Also, minor amounts of clear calcites, free from other mineral inclusions, are present (Fig. 2). According to these textural dissimilarities, calcite found in the carbonatites can be categorized into two types: (i) magmatic ( $70 \%$ of all calcite, Figs 2 and $3 a$ ) and (ii) recrystallized calcite (the rest).

Dolomite ( 20 vol. \%) is the second most common carbonate mineral found in the carbonatites, with five morphological types (Fig. 2): (i) coarse-grained dolomite (type-1), (ii) rod-shaped or vermicular dolomite micro-

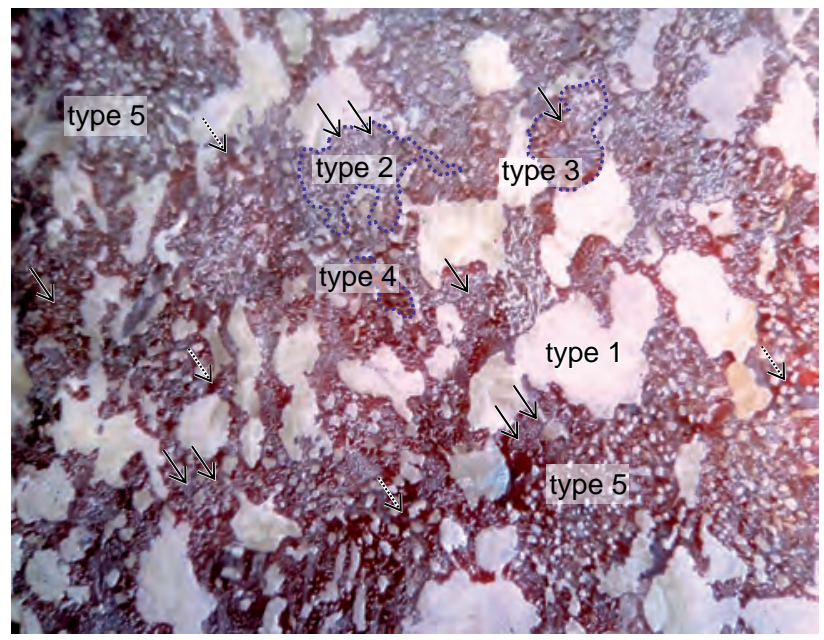

Fig. 2 A view of the stained polished section of the Eppawala carbonatite showing the different types of dolomites (white in colour) and calcite (reddish; solid arrows indicate the type-1 and dashed arrows type-2). 

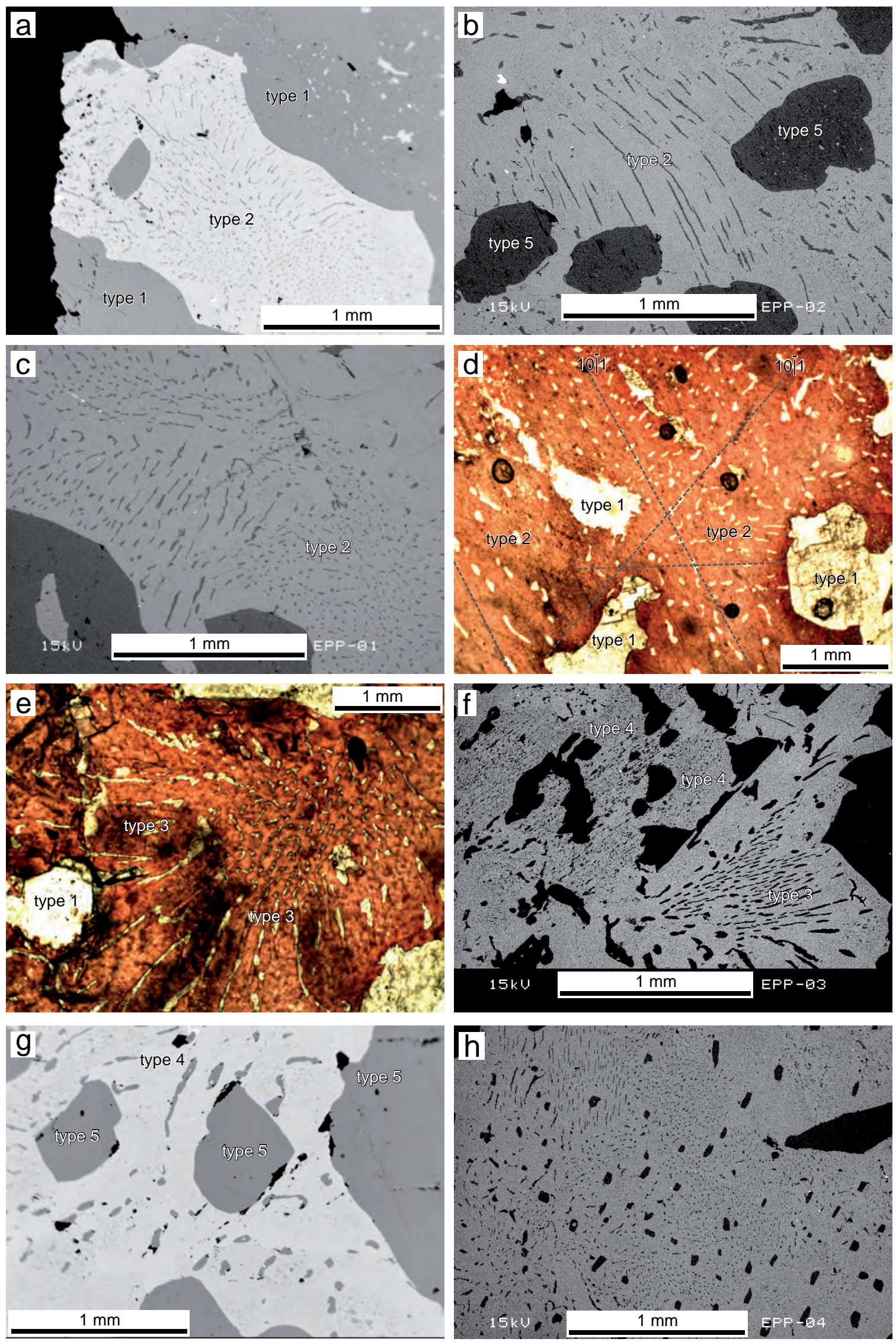
crysts within the type- 1 calcite (type-2), (iii) inclusions of dolomite within the type-1 calcite forming plug- or wedge-shaped arrangements (type-3), (iv) dolomite microcrysts along the grain boundaries of type- 1 calcite (type-4) and (v) clusters of dolomite crosscutting the type-1 calcite (type-5). In addition, some of dolomites are found in association with calcite, forsterite and diopside. Diopside may have formed as a result of hydrothermal alteration of forsterite (Pitawala et al. 2003; Pitawala and Lottermoser 2012); therefore this particular type has not been considered for the present study.

Coarse-grained (5 to $20 \mathrm{~mm}$ ) type- 1 dolomite occurs as discrete grains associated with matrix calcites (Figs 2 and 3a). Grains are anhedral to subhedral with sutured interpenetrating contacts against the matrix calcite. This is the most abundant dolomite type representing c. 50 to 60 vol. $\%$ of the all dolomite.

Type-2 dolomite is the second most common dolomite type in the carbonatites ( 20 vol. \%) and occurs as blebs, rods or vermicules of dolomite microcrysts within the host calcites (Figs 2, 3a-d and h). Blebs and vermicules of type-2 dolomite have variable sizes, whereby grain diameters vary from c. $10 \mu \mathrm{m}$ to a few $100 \mu \mathrm{m}$ (Fig. 3a). The overall appearance is analogous to the texture in perthite feldspar. They are optically parallel and arranged in three different planes. Two of these planes are parallel with cleavage of the host calcite and the remaining system with the common twinning plane of the host calcite (Fig. 3c). As shown in Fig. 4, type-2 dolomite is oriented at different angles to the plane on the surface of the host calcite grains. The dolomite microcrysts in areas (a) to (c) are parallel, and in areas (d) and (e) perpendicular, to the surface of the host calcite grain. The dolomite microcrysts occurring in the area (f) have an oblique orientation. Rod-shaped type-2 dolomite crystals occur as parallel or sub-parallel lamellae (Fig. 3b) in the calcite matrix (type-1). In several samples, the rods are curved at the apexes, hook-like. They are optically parallel with enclosing calcite grains, indicating that they share the c axis. Commonly the rod-shaped dolomite crystals have constant width, but their length varies in the range 50-300 microns.

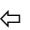

Fig. 3 Back-scattered electron images (a-c, f-h) and photomicrographs (d-e) showing textural diversity of type 2-5 dolomites within the host calcite grains of the Eppawala carbonatite: a - Type-2 dolomite with variable shapes and sizes enclosed by the matrix calcite; $\mathbf{b}$ - Rod-shaped microcrysts of type- 2 dolomite in calcite and subrounded by type- 5 dolomite grains; c - Detail of type-2 dolomite inclusions arranged in different directions; $\mathbf{d}$ - Growth of type-2 dolomite in three distinct crystallographically controlled directions; $\mathbf{e}$ - Plug-like type- 3 dolomite microcrysts appearing as radiating from the center of the host calcite grain; $\mathbf{f}$ - Wedge-like form of type- 3 dolomite and irregular type- 4 dolomites; $\mathbf{g}$ - Segmented rod-shaped type-4 dolomite and coarse subrounded type- 5 dolomite; $\mathbf{h}$ - Diversity of type-2, 4 and 5 dolomites.
}

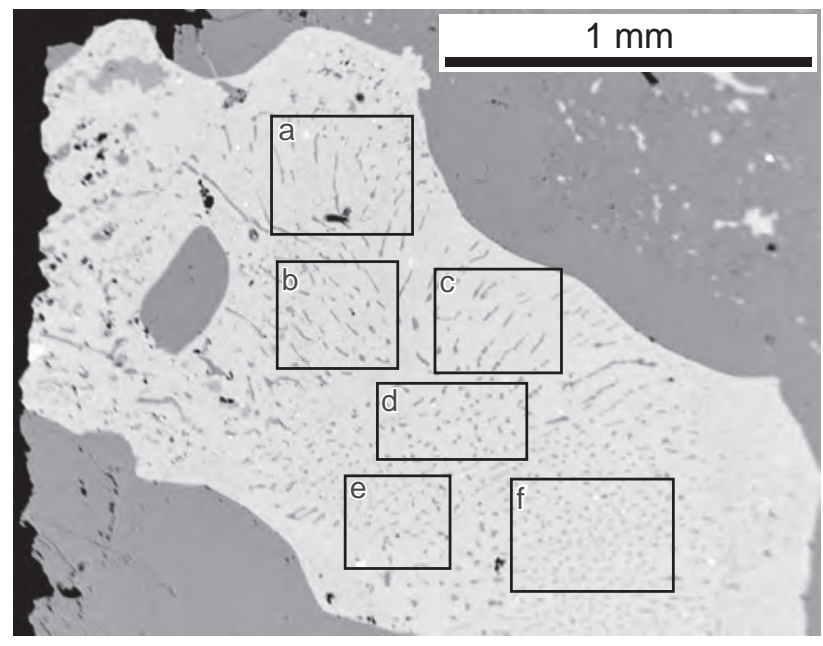

Fig. 4 Photomicrograph of an exsolved magnesian calcite crystal showing different arrangements of dolomite microcrysts. The areas (a) to (c) contain elongated blebs of dolomite microcrysts arranged parallel to the plane; area (d) has dolomite microcrysts in an intermediate position and (e) with (f) areas perpendicular to the plane.

Type-3 dolomite ( $\sim 5$ vol. \%) occurs as intergrowths with type- 1 calcite commonly forming plug- or wedgeshaped arrangements (Figs 2, 3e-f). In the plug-like structures, the dolomite grains in the middle of the enclosing calcite grains are relatively smaller vermicules or blebs $(<20 \mu \mathrm{m})$. The overall appearance resembles the myrmekitic texture and symplectitic intergrowths in some silicate rocks. These dolomites show optical continuity reflecting the single crystal growths. Despite the gradual type-3 dolomite microcrysts size increment towards the rims of the host type- 1 calcite, they show systematic arrangement in core regions of the host calcite (Fig. 3d). The size variation of grains in the observed texture is opposite that typical of myrmekitic intergrowths. In the wedge-shaped form, dolomite occurs as oriented thin short rods (thickness $\sim 20 \mu \mathrm{m}$ ) and all these dolomite microcrysts follow the systematic pattern about the wedge.

Type-4 dolomite ( $\sim 10$ vol. \%) grains are found along the grain boundaries of matrix calcite grains. The dolomites show different morphologies such as plates, rhombohedral facets and segmented rods (Figs 2, 3f-g). They appear like stretched grains along the boundary of the matrix calcites. The grain size of the most of them is in a range of few tens to a several hundreds of micrometres and they do not crosscut the matrix calcites.

Type-5 (12-15 vol. \%) dolomite occurs as clusters of rounded grains in the calcite matrix (Figs 2, 3b, g-h). They show different crystal habits such as granules and disks. Compared to the other studied dolomites, these are relatively large ( $400 \mu \mathrm{m}$ to $2 \mathrm{~mm})$. These dolomites are optically parallel and very often crosscut the calcite matrix. Twinning is prominent in disk-shaped dolomites and twin lamellae are equally developed. 
Tab. 1 Electron-microprobe analyses of calcite of Eppawala Carbonatites (in wt. \%)

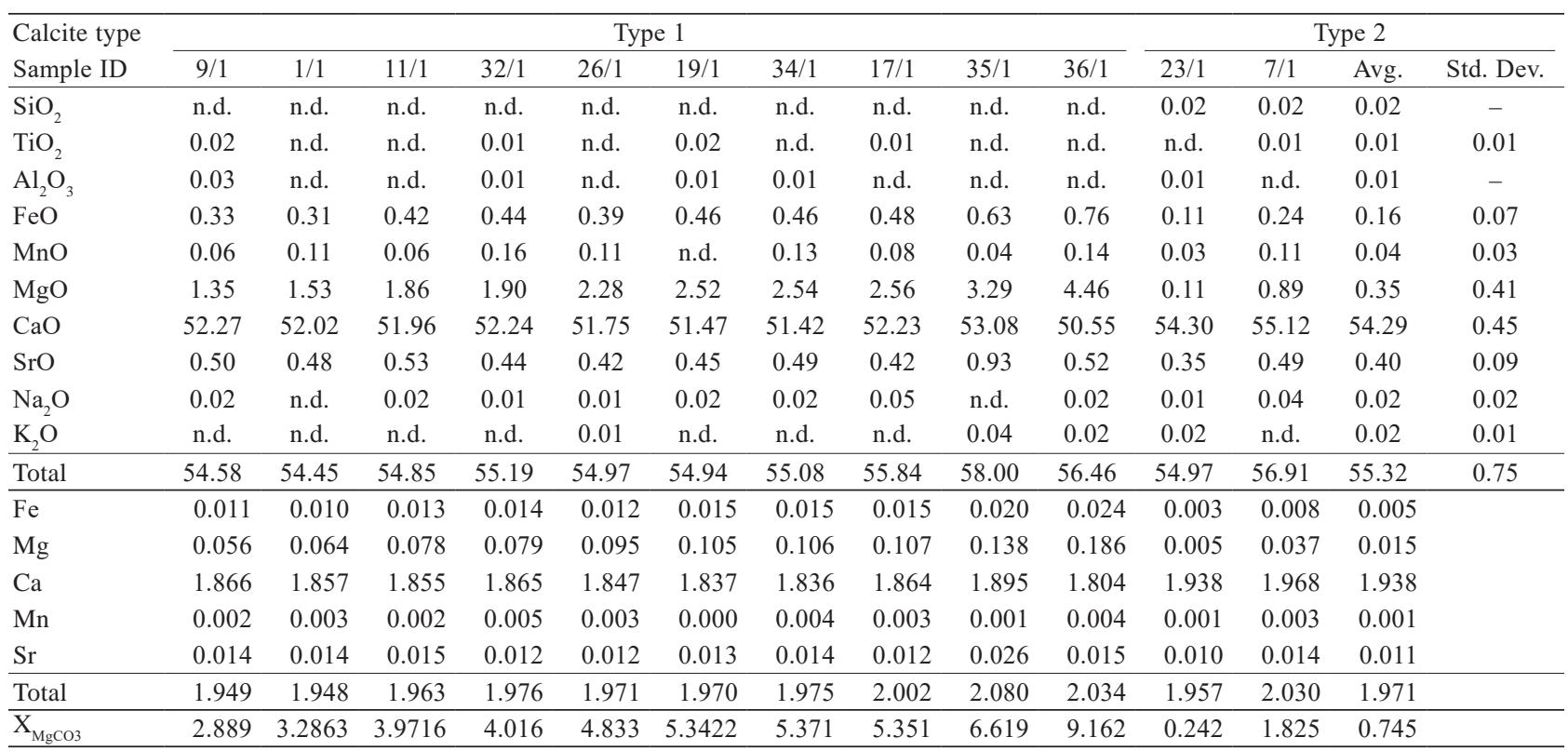

The structural formulae (atoms per formula unit) were calculated on the basis of $2 \mathrm{CO}_{3}{ }^{2}$

n.d. - not detected

\subsection{Chemical composition of carbonate minerals}

The CL images suggest the presence of two compositionally (one rich in $\mathrm{Ca}$ and other rich in $\mathrm{Mg}$ ) different carbonates (Fig. 5) in the studied carbonatites. The XRD spectrum of carbonate phase of the carbonatites confirms the presence of calcite and dolomite. The splitting of the $\{104\}$ diffraction peak of both calcite and dolomite indicates the respective replacement of $\mathrm{Ca}$ and $\mathrm{Mg}$ in their lattices. In particular, asymmetric appearance of the $\{104\}$ calcite peak could be due to the presence of high Mg concentrations.

\subsubsection{Calcite}

Presence of two distinct types of calcites (type-1 and type-2) revealed from the petrographic studies is confirmed by electron-microprobe analyses (Tab. 1). The $\mathrm{Mg}$ content of type- 1 calcite is highly variable $\left(\mathrm{X}_{\mathrm{MgCO} 3}\right.$ $=2.88-9.16)$ and interestingly the type- 1 calcite shows gradual decrease in both $\mathrm{Mg}$ and $\mathrm{Fe}$ contents, similar to the dolomite vermicules (type- 2 and type-3 dolomite; see Figs $6 \mathrm{a}-\mathrm{b}$ and 7). The variability of $\mathrm{Mg}$ content in type-1 calcite is mostly balanced by incorporation of $\mathrm{Ca}$. In addition, type- 1 calcite is rich in $\mathrm{Fe}$ and $\mathrm{Mn}$ and low in Ca compared to type- 2 calcite. In contrast, type- 2
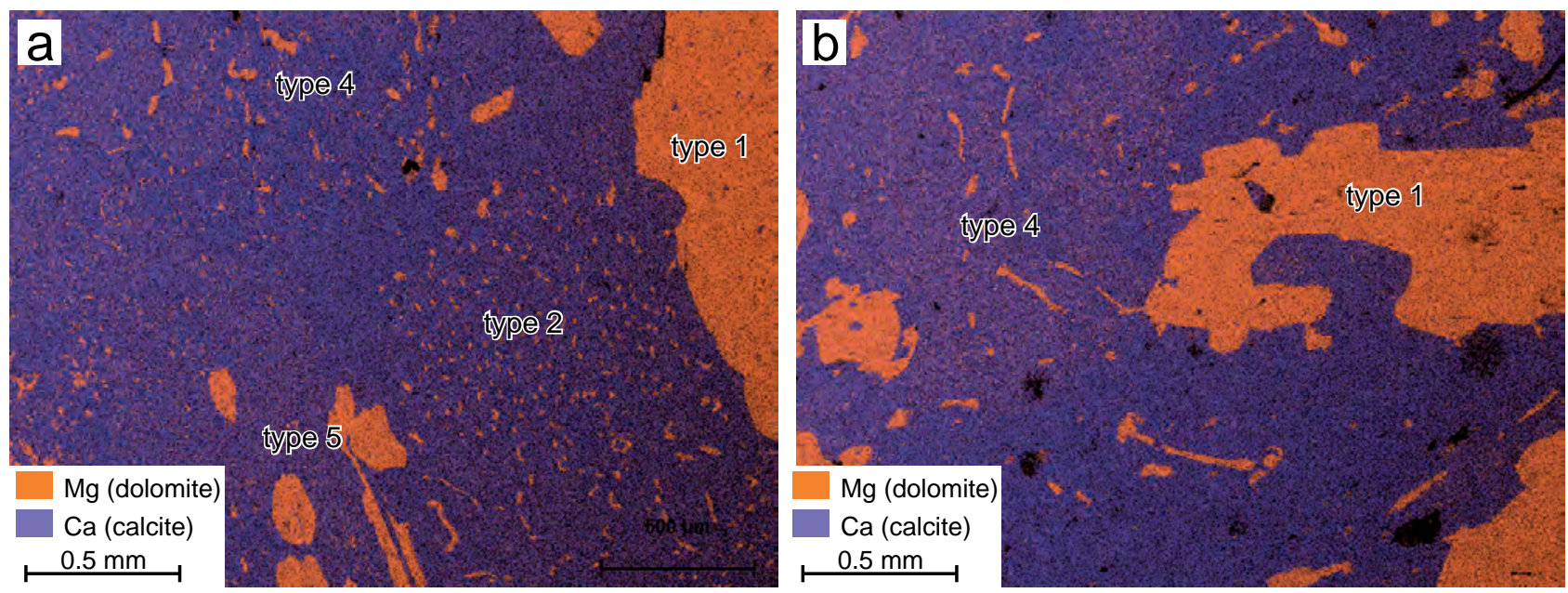

Fig. 5 The CL images showing type-1, 2, 4 and 5 dolomite (orange in colour version of the figure) enclosed in the calcite matrix (blue). 
Tab. 2 Mineral chemistry of dolomite (in wt. \%), represented by discrete analyses and their average compositions

\begin{tabular}{|c|c|c|c|c|c|c|c|c|c|c|c|c|c|c|c|}
\hline \multirow{2}{*}{$\begin{array}{l}\text { Dolomite Type } \\
\text { Data Point }\end{array}$} & \multicolumn{3}{|c|}{ Type 1} & \multicolumn{3}{|c|}{ Type 2} & \multicolumn{3}{|c|}{ Type 3} & \multicolumn{3}{|c|}{ Type 4} & \multicolumn{3}{|c|}{ Type 5} \\
\hline & $3 / 1$ & $\begin{array}{l}\text { Avg. } \\
(n=4)\end{array}$ & $\begin{array}{l}\text { Std. } \\
\text { Dev. }\end{array}$ & $27 / 1$ & $\begin{array}{l}\text { Avg. } \\
(\mathrm{n}=5)\end{array}$ & $\begin{array}{l}\text { Std. } \\
\text { Dev. }\end{array}$ & $15 / 1$ & $\begin{array}{l}\text { Avg. } \\
(\mathrm{n}=8)\end{array}$ & $\begin{array}{l}\text { Std. } \\
\text { Dev. }\end{array}$ & $13 / 1$ & $\begin{array}{l}\text { Avg. } \\
(\mathrm{n}=5)\end{array}$ & $\begin{array}{l}\text { Std. } \\
\text { Dev. }\end{array}$ & $20 / 1$ & $\begin{array}{l}\text { Avg. } \\
(\mathrm{n}=8)\end{array}$ & $\begin{array}{l}\text { Std. } \\
\text { Dev. }\end{array}$ \\
\hline $\mathrm{SiO}_{2}$ & n.d. & 0.01 & 0.02 & 0.01 & 0.01 & 0.01 & 0.02 & 0.06 & 0.08 & 0.03 & 0.01 & 0.01 & n.d. & - & - \\
\hline $\mathrm{TiO}_{2}$ & 0.01 & 0.01 & 0.01 & n.d. & - & - & 0.01 & 0.01 & - . & n.d. & - & - & n.d. & - & - \\
\hline $\mathrm{Al}_{2} \mathrm{O}_{3}$ & n.d. & 0.01 & 0.01 & 0.03 & 0.02 & 0.02 & 0.01 & 0.01 & - & 0.01 & n.d. & - & n.d. & 0.01 & 0.01 \\
\hline $\mathrm{FeO}$ (wt. \%) & 1.45 & 1.45 & 0.03 & 1.65 & 1.62 & 0.09 & 1.68 & 1.64 & 0.05 & 1.81 & 1.81 & 0.07 & 1.40 & 1.34 & 0.08 \\
\hline $\mathrm{MnO}$ & 0.15 & 0.12 & 0.02 & 0.10 & 0.06 & 0.03 & 0.10 & 0.10 & - & 0.13 & 0.15 & 0.02 & 0.09 & 0.09 & 0.04 \\
\hline $\mathrm{MgO}$ & 19.73 & 19.86 & 0.14 & 19.91 & 19.95 & 0.04 & 19.91 & 19.92 & 0.01 & 19.70 & 19.78 & 0.14 & 19.86 & 19.82 & 0.11 \\
\hline $\mathrm{CaO}$ & 30.36 & 30.30 & 0.18 & 30.12 & 30.09 & 0.19 & 30.46 & 30.39 & 0.06 & 30.32 & 30.33 & 0.22 & 30.46 & 30.62 & 0.32 \\
\hline $\mathrm{SrO}$ & 0.17 & 0.20 & 0.04 & 0.22 & 0.22 & 0.01 & 0.22 & 0.22 & - & 0.18 & 0.22 & 0.03 & 0.21 & 0.21 & 0.03 \\
\hline $\mathrm{Na}_{2} \mathrm{O}$ & n.d. & 0.01 & 0.01 & n.d. & 0.01 & 0.01 & 0.02 & 0.01 & - . & 0.01 & 0.02 & 0.02 & 0.04 & 0.01 & 0.02 \\
\hline $\mathrm{K}_{2} \mathrm{O}$ & n.d. & 0.01 & 0.01 & n.d. & - & - & n.d. & - & - & n.d. & - & - & n.d. & - & - \\
\hline Total & 51.86 & 51.98 & 0.11 & 52.03 & 51.98 & 0.14 & 52.42 & 52.37 & 0.14 & 52.18 & 52.33 & 0.36 & 52.06 & 52.11 & 0.22 \\
\hline $\mathrm{Fe}$ (atom) & 0.047 & 0.047 & & 0.053 & 0.052 & & 0.054 & 0.053 & & 0.058 & 0.059 & & 0.045 & 0.043 & \\
\hline Mg & 0.825 & 0.831 & & 0.833 & 0.835 & & 0.833 & 0.833 & & 0.824 & 0.828 & & 0.831 & 0.829 & \\
\hline $\mathrm{Ca}$ & 1.084 & 1.082 & & 1.075 & 1.074 & & 1.087 & 1.085 & & 1.082 & 1.083 & & 1.087 & 1.093 & \\
\hline $\mathrm{Mn}$ & 0.005 & 0.004 & & 0.003 & 0.002 & & 0.003 & 0.003 & & 0.004 & 0.005 & & 0.003 & 0.003 & \\
\hline $\mathrm{Sr}$ & 0.005 & 0.006 & & 0.006 & 0.006 & & 0.006 & 0.006 & & 0.005 & 0.006 & & 0.006 & 0.006 & \\
\hline Total & 1.966 & 1.969 & & 1.971 & 1.969 & & 1.984 & 1.980 & & 1.974 & 1.980 & & 1.972 & 1.975 & \\
\hline $\mathrm{X}_{\mathrm{MgCO} 3}$ & 41.99 & 42.21 & & 42.27 & 42.39 & & 41.99 & 42.08 & & 41.75 & 41.80 & & 42.14 & 42.00 & \\
\hline
\end{tabular}

The structural formulae (atoms per formula unit) were calculated on the basis of $2 \mathrm{CO}_{3}{ }^{2-}$.

$\mathrm{n}$ - number of analyses, n.d. - not detected

calcite shows almost constant $\mathrm{Mg}$ content (average $\mathrm{X}_{\mathrm{MgCO} 3}$ $=1.82$ ). Therefore, it is suggested that these two types of calcite were formed at two separate stages or events.

\subsubsection{Dolomite}

Microprobe analyses of each type of dolomite are shown in Tab. 2. The results show that some dolomite types are chemically comparable, while others have wide range of compositions. Calcium, Mg and $\mathrm{Sr}$ concentrations (Tab. 2) in all types of studied dolomites are comparable. On the other hand, the content of Fe significantly varies among the five different dolomite types. From type- 1 to type- 4 dolomites, the content of Fe gradually increases; in contrast type-5 dolomite shows lower Fe contents, similar to type-1 dolomite. In the $\mathrm{MgO}$ vs. FeO plot, types 1, 2 and 3 dolomites plot within a single cluster, whereas types 4 and 5 fall into separate fields (Fig. 6b). In addition, Ti is detectable only in type-1 dolomite and Mn concentrations are characteristically high in the type-1 dolomite as found
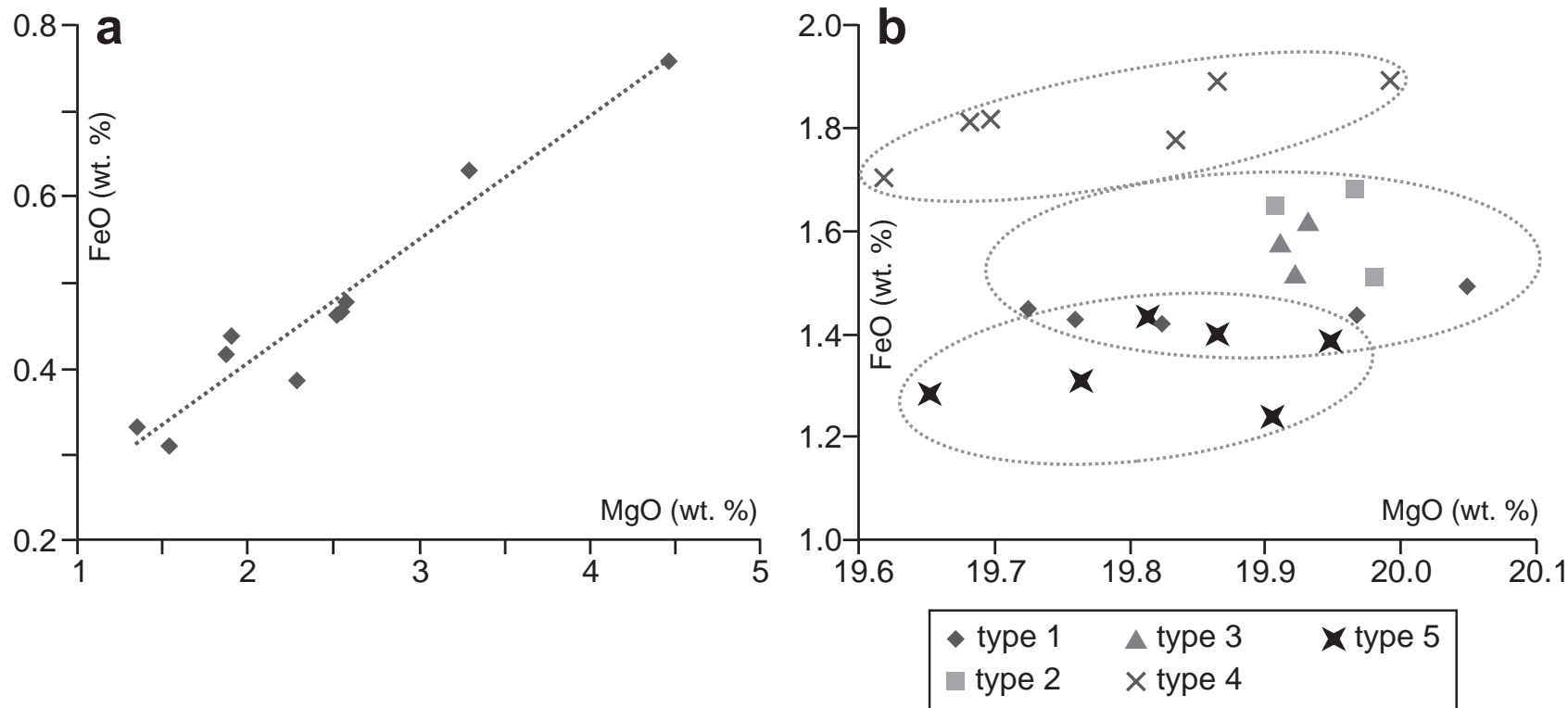

Fig. 6 Plots of $\mathrm{MgO}$ wt. \% vs $\mathrm{FeO}$ wt. \% of investigated type-1 calcite (a) and all dolomite types (b). 


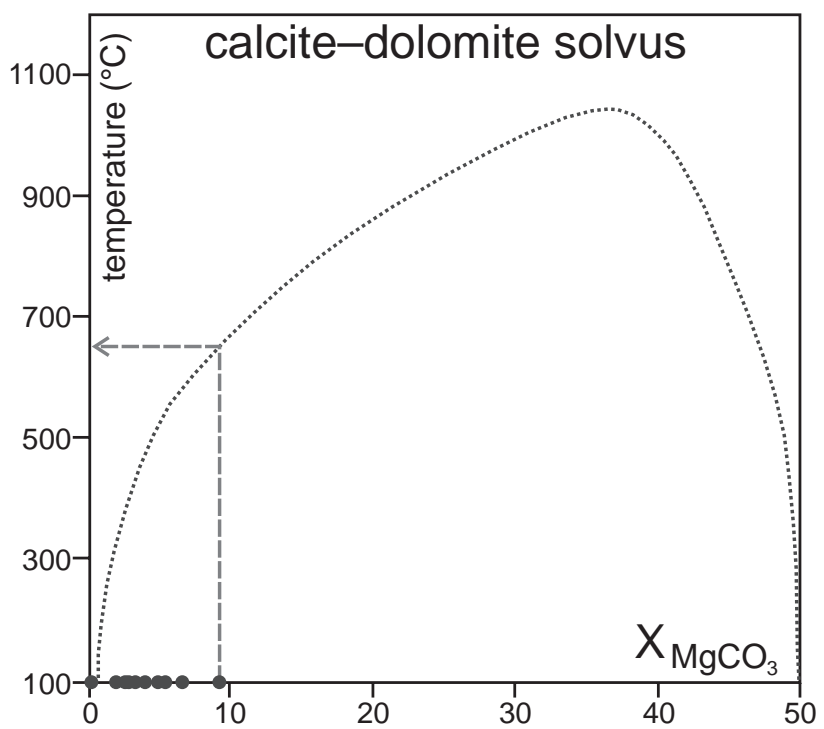

Fig. 7 Calcite-dolomite solvus representing the temperature at which magnesian calcite (type 1) formed and $\mathrm{MgCO}_{3}$ compositions of the investigated magnesian calcite.

in the type- 1 calcite (Tabs 1 and 2). Compared to compositions of type- 1 calcite, the contents of $\mathrm{Mn}$ and $\mathrm{Sr}$ are low in all dolomites.

\section{Discussion}

\subsection{Constraints on the formation of calcites}

Magnesian calcites can be formed in both carbonatites (Carpenter 1967; Zaitsev and Polezhaeva 1994; Pitawala and Lottermoser 2012; Chakhmouradian et al. 2016) and high-grade marbles (Van der Veen 1965; Kretz 1988; Mposkos et al. 2006). However, the analyzed magnesian calcites are rich in $\mathrm{Sr}$ compared to marbles found in the WC as well as elsewhere in the country (Pitawala et al. 2003; Halama et al. 2005). This supports a magmatic origin of the studied magnesian calcite (Halama et al. 2005; Pitawala and Lottermoser 2012; Chakhmouradian et al. 2016). The gradual decrease of both $\mathrm{Mg}$ and Fe contents in calcites towards the type 2 and 3 dolomite lamellae indicates separation of dolomite from primary Mg-rich calcite (Figs 5, 6a; Kretz 1988; Zaitsev and Polezhaeva 1994). Hence, type-1 calcite may have formed through primary magmatic crystallization and only later it may have exsolved to form dolomite lamellae (type 2 and 3). Type-2 calcite is very pure in terms of $\mathrm{Ca}$ (avg. 54.29 wt. \% $\mathrm{CaO}$ ) and it is characterized by low contents of $\mathrm{Fe}, \mathrm{Mn}$, and $\mathrm{Sr}$ compared to type- 1 calcite (Tabs 1 and 2). Type- 2 calcite does not contain any dolomite inclusions. Therefore, these calcites likely originated from different process and could be older than the crystallization of type- 1 calcite.

\subsection{Constraints on formation of the five types of dolomite}

The coarse-grained nature, coexistence with type- $1 \mathrm{cal}-$ cite and the presence of detectable contents of $\mathrm{Mn}$ and $\mathrm{Ti}$ in type-1 dolomite suggest that it has formed simultaneously with the crystallization of Mg-rich (type-1) calcite (Pitawala and Lottermoser 2012).

In contrast, fine-grained type 2 dolomite with different morphological forms is preferably arranged along the cleavage and twin-planes of the enclosing calcite (Fig. 3d). In addition, the enclosing calcite shows gradual decreases of $\mathrm{Mg}$ and $\mathrm{Fe}$ similar to the type- 2 dolomite lamellae as described in the Section 4.2.1. As the particular rock unit undergoes slow cooling, dolomite can be exsolved from the magnesian calcite (Harker and Tuttle 1955; Goldsmith 1960; Goldsmith and Newton 1969; Puhan 1984). Thus, the type-2 dolomite observed in the studied carbonatites could have originated as a product of exsolution from pre-existing magnesian calcite (type-1 calcite) during slow cooling.

Spherulitic appearance of type- 3 dolomite coarsening towards the rims of the host calcite is unique in the studied rocks. The spherulitic texture typically forms as a result of the diffusion of crystal-forming materials during the growth of the host crystal. As a result of specific cooling conditions of the magma, the spherulitic texture can be formed (Watkins et al. 2008). The crystal-forming components become depleted within diffusive lengths around the crystallizing region, but it forms finer particles on the periphery of the host grain. In contrast, type-3 dolomite shows grain coarsening at the rim of the hosting type-1 calcite. Additionally, they occur in optically parallel manner contrary to those observed for symplectitic intergrowths, where optical continuity is more localized with many centres of crystal growth. Therefore, symplectitic intergrowth and spherulitic growth can be ruled out for the type-3 dolomite.

Kretz (1988) observed similar radial arrangement of dolomite microcrysts within calcite of high-grade marbles. In our case, these dolomite microcrysts are arranged systematically throughout the central parts the host calcite, which illustrates the importance of the crystallographic control (Fig. 4b). Thus, the nucleation sites of the type-3 dolomite may have been formed along the crystallographic axes. It can be assumed that this type may have resulted from exsolution of pre-existing magnesian calcite. Resemblance of the chemical compositions of types 2 and 3 also reveals their concomitant formation. However, the grain coarsening at the margins and the disappearance of crystallographic control provide an evidence for the reworking of the early formed exsolved dolomite by later processes. 
Although the finer dolomite types 2 and 3 are confined to the grain interiors, the coarser type-4 dolomite occurs outside of the calcite grains. The amount of type- 4 dolomite is lower than that of both types 2 and 3 . The exsolution was typically restricted to the inner part of the particular host grains. However, under certain conditions, the exsolved grains can be arranged even along the grain boundaries of the host minerals (Wall et al. 1993; Zaitsev and Polezhaeva 1994; Chakhmouradian et al. 2016). Occasional appearance of type- 4 dolomite as discrete grains may be due to the reworking of the exsolved phases by later recrystallization process (Zaitsev and Polezhaeva 1994). Similar exsolution systematics was observed in calcite-carbocernite of carbonatites (Wall et al. 1993), calcite-dolomite of carbonatites (Zaitsev and Polezhaeva 1994), pyroxenes of pyroxenites associated with kimberlites (Alifirova et al. 2012) and products of laboratory simulations (Mercier and Nicolas 1975; Sautter and Fabriès 1990; Weinbruch et al. 2006).

Taken together, the type- 4 dolomite seems a transformed type of exsolved dolomites. The grain-coarsening could be a result of recrystallization as explained by the Zaitsev and Polezhaeva (1994). However, the significant Fe concentrations measured from these dolomites is confusing, since the recrystallization took place within a closed system. Similarly, the type- 4 dolomite occurs in lower modal percentages than that of the types 2 and 3. Based on this result, we can suppose the concomitant volume diffusion of early formed nuclei of the exsolved dolomite towards the grain boundaries of calcite (Balluffi and Cahn 1981; Kretz 1988; Zaitsev and Polezhaeva 1994; Ganguly 2002; Watkins et al. 2008). The Sr content of the type- 4 dolomite is comparable with the values obtained for types 2 and 3 . Hence, the process of recrystallization should have been responsible for forming coarse type-4 dolomite, which permitted high diffusion of Fe. Such volume diffusion of materials may +cause coarsening of the pre-existing exsolution lamellae, as explained by Brady (1987). Volume diffusion induced by recrystallization may have been supplied by the components needed in coarsening of the type- 3 dolomite near to the grain margins of the host calcites.

The crosscutting, very coarse-grained clusters of individual type-5 dolomite grains must represent the youngest generation. Optically parallel nature of all individual microcrysts of type- 5 dolomites found in a specific grain-cluster indicates simultaneous crystallization. In addition, they have typically low $\mathrm{Fe}$ and high $\mathrm{Sr}$ contents, comparable to those in matrix dolomite grains. For that reason, type- 5 dolomite could be a result of postrecrystallization processes of the matrix dolomite grains (Grigorev 1961; Zhabin 1971). Type-2 calcite, which has low Mg but high Sr contents, may have formed simultaneously from earlier calcites.

\subsection{Exsolution systematics}

The observed types of dolomite within carbonatite show a succession in morphology; thin lamellae (types 2 and 3 ), coarser microcrysts along the grain boundaries of calcite (type-4) and coarse individual grains crosscutting the matrix calcite (type-5). Simultaneously, dolomites progressively increase in size. The morphology, modal proportions and compositions of the exsolved dolomite can be used to interpret the prevailing sub-solidus chemical and P-T conditions (Carpenter 1967; Zaitsev and Polezhaeva 1994).

The studied exsolved dolomite microcrysts show varieties of grain shapes and distributions, which imply that the exsolution was controlled by a nucleation rate. The crystallographically oriented type- 2 dolomite indicates that the nucleation occurred preferably along the twin planes and the cleavage of the host magnesian calcite. The formation of such abundant exsolved minerals needs residence at relatively low temperature and/or low pressure for a long period of time.

If dolomites grew by a process similar to that of the exsolution, the temperature of the event can be calculated based on the composition of primary magnesian calcite (Goldsmith and Newton 1969; Puhan 1976; Goldsmith 1983). The calculated temperatures must be considered as minimal; the highest temperatures can be derived from the highest $\mathrm{Mg}$ content found in calcite. According to the calcite-dolomite solvus (Goldsmith 1983; Anovitz and Essene 1987), the temperature of exsolution of studied dolomite from magnesian calcite is expected to be $c$. $650-655^{\circ} \mathrm{C}$ (Fig. 7). Although such exsolution textures are observed in some carbonatites that have originated by fractional crystallization (Zaitsev and Polezhaeva 1994), this is the first record of such textures noted from carbonatites produced by partial melting of mantle peridotites. Hence, these observations are important even in advancing the petrographical records of carbonatites.

\subsection{Recrystallization systematics}

Formation of dolomite types 4 and 5 and type- 2 calcite with simultaneous coarsening of type- 2 and 3 dolomite may have occurred concurrently as a result of recrystallization. This process allows the modification of preexisting composition by exchanging the components like Fe. Carbonate minerals in the studied rocks were continuously recrystallized, but the other minerals (silicates, sulphides and oxides) remained unchanged during this process (Pitawala and Lottermoser 2012). Recrystallization of a particular magmatic rock may have several causes: (i) regional stress, tectonic compression and/or shearing at post-convective stage of magmatic body while ascending to the crust (Paterson and Fowler 
1993; Barros et al. 2001), (ii) magma movements shortly after its emplacement (Nesbitt and Kelly 1977) and (iii) deformations after emplacement (e.g., during metamorphism). Similarly, recrystallization fronts are observed in the magmatic rocks that have suffered partial melting or infiltration of asthenospheric fluids (Van der Wal and Bodinier 1996; Garrido and Bodinier 1999).

According to the $\mathrm{Rb}-\mathrm{Sr}$ and $\mathrm{Sm}-\mathrm{Nd}$ isotopic data, the Eppawala carbonatites have been emplaced during late Neoproterozoic times (550 Ma: Weerakoon et al. 2001); i.e. after the peak of country-rock metamorphism ( $\sim 610$ Ma: Kröner and Williams 1993). Preservation of the most of the magmatic textures (Pitawala et al. 2003; Pitawala and Lottermoser 2012; Madugalla et al. 2014) and lack of deformation support the idea of post-metamorphic emplacement (Pitawala and Lottermoser 2012). Hence, the recrystallization of carbonate minerals was not induced by metamorphism.

Additionally, as explained above, the carbonate minerals of the studied rocks show pervasive exsolution and such exsolved phases are common in many carbonatite bodies in the World (Van der Veen 1965; Zaitsev and Polezhaeva 1994). For the formation of such textures, long undisturbed cooling is needed. Similarly, most of the exsolved dolomites which are near to the grain boundaries expanded.

The exsolution and the grain-growth processes followed by recrystallization were probably not coeval. Hence, it is suggested that the re-equilibration of carbonatite magma took place at two distinct stages; recrystallization may have occurred at shallower depth, after the exsolution process.

Carbonate rocks are able to accommodate large amounts of strain, and deform crystals plastically even at very low T and/or P conditions (Bestmann et al. 2000 and references therein; Ulrich et al. 2002; Schenk et al. 2005). The minimum temperature for crystal plasticity of calcite is about $180^{\circ} \mathrm{C}$ (e.g. Burkhard 1990). Under high stresses, carbonate minerals of carbonatites can behave as a plastic material. Thus, the local tectonic stresses developed in the deeper parts of the crust, where carbonatite body had already been emplaced, may have caused partial melting of the carbonate fraction of carbonatite as carbonates partially melt at low temperatures (Wyllie 1965; Wenzel et al. 2002). Subsequently, highly strained, plastic carbonatite melt may have been squeezed out to a shallower depth, having re-equilibrated at shallow crustal conditions (Corti et al. 2003; Rosenberg 2004 and references therein). This plastic movement is evident by the presence of flow texture marked by apatite megacrysts, fractured fine grains of apatite and folded ilmenite grains with different directional fold axes (Pitawala et al. 2003; Pitawala and Lottermoser 2012). The second emplacement could have been responsible for the observed syn-deformational-dynamic recrystallization textures in carbonate minerals. Such upward squeezing of particular magmatic body can occur due to crustal compression (Bailey 1961; Woolley 1989; Brown and Solar 1999).

Comparable carbonatite magmatism took place in East Gondwanan fragments of Southern India and East African Orogen (Santosh et al. 1989; Stern 1994; Collins and Pisarevsky 2005) during the amalgamation of Gondwana (Neoproterozoic to Cambrian). Consequently, as part of the East Gondwana fragment, Sri Lanka may also have experienced comparable magmatism. However, the WC of Sri Lanka suffered strong deformation that post-dated the final amalgamation of Gondwana (Kehelpannala 2003; Kröner et al. 2003). This deformation was due to collision between pre-amalgamated unit of the $\mathrm{WC} / \mathrm{HC}$ with the VC ( $\sim 550$ Ma: Berger and Jayasinghe 1976; Kehelpannala 2003; Kröner et al. 2003) and it was the last significant deformation experienced by the $\mathrm{WC}$, in which this unit has been affected by collisional tectonics.

According to above-described connection between the inferred tectonic regime and the genesis of Eppawala carbonatites, it can be argued that the carbonatite body has been emplaced coeval with Gondwana amalgamation. The late collision between pre-amalgamated units of $\mathrm{WC} / \mathrm{HC}$ and the $\mathrm{VC}$ may have caused the movement of the Eppawala carbonatites to a shallower level. Such interpretation is further supported by lack of any tectonicrelated textures in the carbonatite bodies (Pitawala et al. 2003; Manthilake et al. 2008; Pitawala and Lottermoser 2012) except for the recrystallization textures of carbonate minerals.

\subsection{Primary crystallization and subsolidus history of carbonatites}

According to observations described above, type- 1 calcite and the type- 1 dolomite are the primary carbonate minerals, which crystallized from the carbonatite magma (see also Pitawala and Lottermoser 2012). Even though type-1 dolomite and type- 1 calcite show coarse-grained textures, any of them did not form such large grains as apatite. Therefore, we suggest that they grew under relatively fast cooling conditions. Compared to silicate melts, the less viscous carbonate melts can remain physically unchanged even under the upper crustal conditions and easily ascend into the crust (Harmer and Gittins 1997). The emplacement of the carbonatite magma with its initial crystallized products may have resulted in rapid cooling and end of convection in the core of the magma chamber (Treiman and Schedl 1983; Andersson et al. 2013). The type-1 calcite and dolomite may have crystallized at similar conditions within the crust. The coexistence of type-1 calcite and type-1 dolomite reflects equilibrium during simultaneous crystallization of carbonatite magma. The 
calculated exsolution temperature of $c .650^{\circ} \mathrm{C}$ was lower than the temperature of this crystallization. Strontium concentration in magnesian calcite is higher than that of the type- 1 dolomite, probably as a result of high preference of $\mathrm{Sr}$ in the calcite structure (Jacobson and Usdowski 1976; Machel 1985; Banner 1995).

The second process that modified the mineralogical and textural characteristics of the carbonate phase was exsolution. It may have occurred in subsolidus, when the magnesian calcites exsolved to form dolomite and calcite with lower Mg contents (Tab. 1). The exsolution likely continued for a longer period of time under a specific temperature, allowing formation of large amounts of exsolved phases (type-2 and 3 dolomite). This process may have been finally inhibited by diminishing diffusion of the rate-controlling components.

Then the recrystallization occurred during the second plastic movement of plutons to a shallow crust, which permitted the volume diffusion of materials and coarsening of some lamellae of type- 2 and 3 dolomites as well as the growth of type- 4 dolomite. The type- 5 dolomite and type- 2 calcite may have formed as a result of the same recrystallization process.

\section{Conclusions}

Textures of carbonate minerals in the Eppawala carbonatites suggest that they have undergone equilibrations at two distinct crustal depths. Initially, within-crust emplaced carbonatite body experienced post-magmatic cooling yielding exsolution of primary magmatic calcite. Subsequently squeezing of the carbonatite body to the upper crust has taken place resulting in recrystallization and rearrangement of carbonate minerals.

The study shows that there is a strong relationship between the textures of carbonate minerals and the petrogenetic history of carbonatites. Syn- to post-magmatic processes modify the grain-size, shape, orientation and the modal proportions of carbonate minerals significantly. Study of these textures of carbonate minerals with their geochemical characteristics is important in unravelling the prevailing conditions and kinetics of the processes that modify them. Hence, the depth investigations on textural characteristics of carbonate minerals are capable of giving direct information about the magmatic to subsolidus history of carbonatites.

Acknowledgements. The authors acknowledge the funding from National Research Council (Grant No. 11/178), Sri Lanka. The chemical analysis at Laboratoire Magmas et Volcans, Université Blaise Pascal, France were financially financed by INSU-CNRS PNP-2013 research grant to Geeth Manthilake. Further, we are grateful to Dr. T.
Hammouda in Laboratoire Magmas et Volcans, Université Blaise Pascal, France for the support in course of the SEM analyses and his constructive comments during the study. The authors thank to Journal of Geosciences reviewers D. Upadhyay and V. T. McLemore, as well as handling editor V. Rapprich, for their constructive comments which have helped in improving of the manuscript.

\section{References}

Alifirova TA, Pokhilenko LN, Ovchinnikov YI, DonNelly CL, Riches AJ, TAYlor LA (2012) Petrologic origin of exsolution textures in mantle minerals: evidence in pyroxenitic xenoliths from Yakutia kimberlites. Int Geol Rev 54: 1071-1092

Andersson M, Malehmir A, Troll VR, Dehghannejad M, Juhlin C, Ask M (2013) Carbonatite ring-complexes explained by caldera-style volcanism. Sci Rep 3: 1677

Anovitz LM, Essene EJ (1987) Phase equilibria in the system $\mathrm{CaCO}_{3}-\mathrm{MgCO}_{3}-\mathrm{FeCO}_{3}$. J Petrol 2: 389-415

BAILEY DK (1961) The mid-Zambezi-Luangwa rift and related carbonatite activity. Geol Mag 98: 277-284

BALlufFi RW, CAHN JW (1981) Mechanism for diffusion induced grain boundary migration. Acta Metall 29: 493-500

BANNER JL (1995), Application of the trace element and isotope geochemistry of strontium to studies of carbonate diagenesis. Sedimentology 42: 805-824

Barros CEM, Barbey P, Boullier AM (2001) Role of magma pressure, tectonic stress and crystallization progress in the emplacement of syntectonic granites. The A-type Estrela Granite Complex (Carajás Mineral Province, Brazil). Tectonophysics 343: 93-109

BELL K (1998) Radiogenic isotope constraints on relationships between carbonatites and associated silicate rocks: a brief review. J Petrol 39: 1987-1996

Bell K, Blenkinsop J (1987) Archean depleted mantle: evidence from $\mathrm{Nd}$ and $\mathrm{Sr}$ initial isotopic ratios of carbonatites. Geochim Cosmochim Acta 51: 291-298

Bell K, Simonetti A (2010) Source of parental melts to carbonatites - critical isotopic constraints. Mineral Petrol 98: 77-89

Bell K, Tilton GR (2001) Nd, Pb and Sr isotopic compositions of East African carbonatites: evidence for mantle mixing and plume inhomogeneity. J Petrol 42: 1927-1945

Berger AR, Jayasinghe NR (1976) Precambrian structure and chronology in the Highland Series of Sri Lanka. Precambr Res 3: 559-576

Bestmann M, Kunze K, Matthews A (2000) Evolution of a calcite marble shear zone complex on Thassos Island, Greece: microstructural and textural fabrics and their kinematic significance. J Struct Geol 22: 1789-1807 
BRADY JB (1987) Coarsening of fine-scale exsolution lamellae. Amer Miner 72: 697-706

Brown M, Solar GS (1999) The mechanism of ascent and emplacement of granite magma during transpression: a syntectonic granite paradigm. Tectonophysics 312 : 1-33

BurKHARD M (1990) Ductile deformation mechanisms in micritic limestones naturally deformed at low temperatures (150-350 ${ }^{\circ} \mathrm{C}$ ). In: KNIPE RJ, RutTer EH (eds) Deformation Mechanisms, Rheology and Tectonics. Geological Society of London, Special Publications 54: pp 241-257

CARPENTER AB (1967) Mineralogy and petrology of the system $\mathrm{CaO}-\mathrm{MgO}-\mathrm{CO}_{2}-\mathrm{H}_{2} \mathrm{O}$ at Crestmore, California. Amer Miner 52: 1341-1363

Chakhmouradian AR, Reguir EP, Zaitsev AN (2016) Calcite and dolomite in intrusive carbonatites. I. Textural variations. Mineral Petrol 110: 333-360

Collins AS, Pisarevsky SA (2005) Amalgamating eastern Gondwana: the evolution of the Circum-Indian orogens. Earth Sci Rev 71: 229-270

CoOper AF, ReID DL (1991) Textural evidences for calcite carbonatite magmas, Dicker Willem, Southwest Namibia. Geology 19: 1193-1196

Cooray PG (1984) An Introduction to the Geology of Sri Lanka (Ceylon), $2^{\text {nd }}$ revised edition. National Museums of Sri Lanka Publication, Colombo, pp 1-340

Cooray PG (1994) The Precambrian of Sri Lanka: a historical review. Precambr Res 66: 3-18

Corti G, Bonini M, Conticelli S, Innocenti F, Manetti P, SoKoutis D (2003) Analogue modeling of continental extension: a review focused on the relations between the patterns of deformation and the presence of magma. Earth Sci Rev 63: 169-247

FRIEDMAN GM (1959) Identification of carbonate minerals by staining methods. J Sediment Res 29: 87-97

GANGULY J (2002) Diffusion kinetics in minerals: principles and applications to tectono-metamorphic processes. In: Gramaccioli C (ed) Energy Modelling in Minerals. European Mineralogical Union Notes in Mineralogy 4: pp 271-309

GARRIDO CJ, BODINIER JL (1999) Diversity of mafic rocks in the Ronda peridotite: evidence for pervasive melt-rock reaction during heating of subcontinental lithosphere by upwelling asthenosphere. J Petrol 40: 729-754

GOLDSMITH JR (1960) Exsolution of dolomite from calcite. J Geol 68:103-109

GoLDSMITH JR (1983) Phase relations of rhombohedral carbonates. In: REEDER RJ (ed) Carbonates: Mineralogy and Chemistry. Mineralogical Society of America Reviews in Mineralogy and Geochemistry 11: pp 49-76

Goldsmith JR, Newton RC (1969) PTX-relations in the system $\mathrm{CaCO}_{3}-\mathrm{MgCO}_{3}$ at high temperatures and pressures. Amer J Sci 267-A: 160-190

Grigorev DD (1961) Ontogeny of Minerals. Izdatel'stvo L'vovskogo Universiteta, Lvov, pp 1-250 (in Russian)
Halama R, Vennemann T, Siebel W, Markl G (2005) The Grønnedal-Ika carbonatite-syenite complex, South Greenland: carbonatite formation by liquid immiscibility. J Petrol 46: 191-217

Halama R, McDonough WF, Rudnick RL, Bell K (2008) Tracking the lithium isotopic evolution of the mantle using carbonatites. Earth Planet Sci Lett 265: 726-742

Harker RI, Tuttle OF (1955) Studies in the system $\mathrm{CaO}-\mathrm{MgO}-\mathrm{CO}_{2}$; Part 2, Limits of solid solution along the binary join $\mathrm{CaCO}_{3}-\mathrm{MgCO}_{3}$. Amer J Sci 253: 274-282

HARMer RE, Gittins J (1997) The origin of dolomitic carbonatites: field and experimental constraints. J Afr Earth Sci 25: 5-28

JACOBSON RL, UsDowski HE (1976) Partitioning of strontium between calcite, dolomite and liquids: an experimental study under higher temperature diagenetic conditions, and a model for the prediction of mineral pairs for geothermometry. Contrib Mineral Petrol 59: 171-185

JAYAWARDENA D (1976) The Eppawala carbonatite complex in north-west Sri Lanka. Economic Bulletin No 3. Geological Survey Department, Colombo, pp 20-71

Johnson CM, Bell K, Beard BL, Shultis AI (2010) Iron isotope compositions of carbonatites record melt generation, crystallization, and late-stage volatile-transport processes. Mineral Petrol 98: 91-110

Katz K, Keller J (1981) Comb-layering in carbonatite dykes. Nature 294: 350-352

KeHELPANNALA KVW (1997) Deformation of a high-grade Gondwana fragment, Sri Lanka. Gondwana Res 1: 47-68

KeHELPANNALA KVW (2003) Structural evolution of the middle to lower crust in Sri Lanka - a review. J Geol Soc Sri Lanka 11: 45-85

Keller J, Zaitsev AN (2006) Calciocarbonatite dykes at Oldoinyo Lengai, Tanzania: the fate of natrocarbonatite. Canad Mineral 44: 857-876

KJarsgaard B, Peterson T (1991) Nephelinite-carbonatite liquid immiscibility at Shombole volcano, East Africa: petrographic and experimental evidence. Mineral Petrol 43: 293-314

KRETZ R (1988) SEM study of dolomite microcrystals in Grenville marble. Amer Miner 73: 619-631

KRÖNER A, WILliams IS (1993) Age of metamorphism in the high-grade rocks of Sri Lanka. J Geol 101: 513-521

KröNER A, COORAY PG, VitANAGE PW (1991) Lithotectonic subdivision of the Precambrian basement in Sri Lanka. In: KRÖNER A (ed) The Crystalline Crust of Sri Lanka Pt I. Summary of Research of the German-Sri Lanka Consortium. Geol Surv Dept Sri Lanka Prof Pap 5: pp 5-21

Kröner A, Kehelpannala KVW, Hegner E (2003) Ca 750-1100 Ma magmatic events and Grenville-age deformation in Sri Lanka: relevance for Rodinia supercontinent formation and dispersal, and Gondwana amalgamation. J Asian Earth Sci 22: 279-300 
LENTZ DR (1999) Carbonatite genesis: a re-examination of the role of intrusion-related pneumatolytic skarn processes in limestone melting. Geology 27: 335-338

Le RoEx AP, Lanyon R (1998) Isotope and trace element geochemistry of Cretaceous Damaraland lamprophyres and carbonatites, northwestern Namibia: evidence for plume-lithosphere interactions. J Petrol 39: 1117-1146

MACHEL HG (1985) Cathodoluminescence in calcite and dolomite and its chemical interpretation. Geosci Can 12: 139-147

Madugalla tBNS, Pitawala HMTGA, Karunaratne DGGP (2014) Use of carbonatites in the production of precipitated calcium carbonate: a case study from Eppawala, Sri Lanka. Nat Res 23: 217-229

ManthilaKe MAGM, SaWAda Y, SaKai S (2008) Genesis and evolution of Eppawala carbonatites, Sri Lanka. J Asian Earth Sci 32: 66-75

Mercier JC, Nicolas A (1975) Textures and fabrics of upper-mantle peridotites as illustrated by xenoliths from basalts. J Petrol 16: 454-487

Milisenda CC, Liew TC, HofMann AW, Kröner A (1988) Isotopic mapping of age provinces in Precambrian highgrade terrains: Sri Lanka. J Geol 96: 608-615

Milisenda CC, Liew TC, Hofmann AW, KöHLER H (1994) $\mathrm{Nd}$ isotopic mapping of the Sri Lanka basement: update, and additional constraints from $\mathrm{Sr}$ isotopes. Precambrian Res 66: 95-110

MoROGAN V (1994) Ijolite versus carbonatite as sources of fenitization. Terra Nova 6: 166-176

Morogan V, Martin RF (1985) Mineralogy and partial melting of fenitized crustal xenoliths in the Oldoinyo Lengai carbonatitic volcano, Tanzania. Amer Miner 70: 1114-1126

Mposkos E, Baziotis I, Proyer A, Hoinkes G (2006) Dolomitic marbles from the ultrahigh-pressure metamorphic Kimi Complex in Rhodope, NE Greece. Mineral Petrol 88: 341-362

Nesbitt BE, Kelly WC (1977) Magmatic and hydrothermal inclusions in carbonatite of the Magnet Cove Complex, Arkansas. Contrib Mineral Petrol 63: 271-294

Paterson SR, Fowler TK (1993) Extensional plutonemplacement models: do they work for large plutonic complexes? Geology 21: 781-784

Pitawala A, Lottermoser BG (2012) Petrogenesis of the Eppawala carbonatites, Sri Lanka: a cathodoluminescence and electron microprobe study. Mineral Petrol 105: 57-70

Pitawala A, Schidlowski M, Dahanayake K, Hofmeister W (2003) Geochemical and petrological characteristics of Eppawala phosphate deposits, Sri Lanka. Miner Depos 38: 505-515

PuHAN D (1976) Metamorphic temperature determined by means of the dolomite-calcite solvus geothermometerexamples from the Central Damara Orogen (South West Africa). Contrib Mineral Petrol 58: 23-28
Puhan D (1984) Microtexture of dolomite within exsolved magnesian calcite examples from the Damara orogen (Namibia). Contrib Mineral Petrol 87: 98-99

Ray JS, Ramesh R (2006) Stable carbon and oxygen isotopic compositions of Indian carbonatites. Int Geol Rev 48: 17-45

RosenberG CL (2004) Shear zones and magma ascent: a model based on a review of the Tertiary magmatism in the Alps. Tectonics 23: 1-21

Santosh M, IYer SS, Vasconcellos MBA, ENZWEILER J (1989) Late Precambrian alkaline plutons in southwest India: geochronologic and rare-earth element constraints on Pan-African magmatism. Lithos 24: 65-79

SAUTTER V, FABRIÈs J (1990) Cooling kinetics of garnet websterites from the Freychinede orogenic lherzolite massif, French Pyrenees. Contrib Mineral Petrol 105: 533-549

Schenk O, Urai JL, Evans B (2005) The effect of water on recrystallization behavior and grain boundary morphology in calcite - observations of natural marble mylonites. J Struct Geol 27: 1856-1872

Skelton A, Vuorinen JH, Arghe F, Fallick A (2007) Fluid-rock interaction at a carbonatite-gneiss contact, Alnö, Sweden. Contrib Mineral Petrol 154: 75-90

STERN RJ (1994) Arc-assembly and continental collision in the Neoproterozoic African Orogen: implications for the consolidation of Gondwanaland. Ann Rev Earth Planet Sci 22: 319-351

TiLTON GR, BeLL K (1994) Sr-Nd-Pb isotope relationships in Late Archean carbonatites and alkaline complexes: applications to the geochemical evolution of Archean mantle. Geochim Cosmochim Acta 58: 3145-3154

Treiman AH, Schedl A (1983) Properties of carbonatite magma and processes in carbonatite magma chambers. J Geol 91: 437-447

Ulrich S, Schulmann K, Casey M (2002) Microstructural evolution and rheological behavior of marbles deformed at different crustal levels. J Struct Geol 24: 979-995

Van Der Veen AH (1965) Calcite dolomite intergrowths in high temperature carbonate rocks. Amer Miner 50: 2070-2077

VAn Der Wal D, Bodinier JL (1996) Origin of the recrystallisation front in the Ronda peridotite by km-scale pervasive porous melt flow. Contrib Mineral Petrol 122: 387-405

Wall F, Le Bas MJ, Srivastava RK (1993) Calcite and carbocernaite exsolution and cotectic textures in a Sr, REE-rich carbonatite dyke from Rajasthan, India. Mineral Mag 57: 495-513

Watkins J, Manga M, Huber C, Martin M (2008) Diffusion-controlled spherulite growth in obsidian inferred from $\mathrm{H}_{2} \mathrm{O}$ concentration profiles. Contrib Mineral Petrol 157: $163-172$

Weerakoon MWK, Miyazaki T, Shuto K, Kagami $\mathrm{H}$ (2001) Rb-Sr and Sm-Nd geochronology of the 
Eppawala metamorphic rocks and carbonatite, Wanni Complex, Sri Lanka. Gondwana Res 4: 409-420

Weinbruch S, Styrsa V, Dirsch T (2006) The size distribution of exsolution lamellae in iron-free clinopyroxene. Amer Miner 91: 551-559

Wenzel T, Baumgartner LP, Brugmann GE, Konnikov EG, KISLOV EV (2002) Partial melting and assimilation of dolomitic xenoliths by mafic magma: the Ioko-Dovyren Intrusion, North Baikal Region, Russia. J Petrol 43: 2049-2074

Woolley AR (1989) The spatial and temporal distribution of carbonatites. In: BELL K (ed) Carbonatites: Genesis and Evolution. Unwin Hyman, London, pp 15-37
Wyllie PJ (1965) Melting relationships in the system $\mathrm{CaO}-\mathrm{MgO}-\mathrm{CO}_{2}-\mathrm{H}_{2} \mathrm{O}$, with petrological applications. J Petrol 6: 101-123

Wyllie PJ, BAKer MB, White BS (1990) Experimental boundaries for the origin and evolution of carbonatites. Lithos 26: 3-19

Zaitsev A, Polezhaeva L (1994) Dolomite-calcite textures in early carbonatites of the Kovdor ore deposit, Kola Peninsula, Russia: their genesis and application for calcite-dolomite geothermometry. Contrib Mineral Petrol 115: 339-334

ZHABIN AG (1971) Primary textural-structural features of carbonatites and their metamorphic evolution. Int Geol Rev 13: 1087-1096 